\title{
Mikrosefali ile İlişkili Genetik Faktörler \\ Genetic Disorders Associated with Microcephaly
}

\author{
• Esra KILIÇ
}

Sağlık Bilimleri Üniversitesi, Ankara Çocuk sağlığı ve Hastalıkları Hematoloji Onkoloji SUAM, Çocuk Genetik Bölümü, Ankara, Türkiye

\begin{abstract}
ÖZ
Mikrosefali bir hastalık değildir, bir klinik bulgudur ve öğrenme güçlüğü ile sıklıkla ilişkili olan azalmış intrakranyal beyin hacmini tahmin etmemizi sağlar. İntrauterin nöronal gelişimdeki anormal süreç primer mikrosefaliye sebep olur. Sekonder mikrosefali doğumdan sonra gelișir ve sıklkkla beyaz cevher hastallıları ile ilișkilidir. Mikrosefalinin altında yatan etyolojik sebepler kompleks veya multifaktöriyel olabilir. Bu sebepler, anormal mitotik iplikcik yapısı, anormal sentrozomal protein yapısı, bozuk siliyer fonksiyon, bozuk DNA tamir mekanizması ve replikasyon bozukluklarını içerir. Biz burada primer konjenital ve sekonder gelişimsel mikrosefalinin genetik faktörlerini gözden geçireceğiz.
\end{abstract}

Anahtar Sözcükler: Zihinsel yetersizlik, Mikrosefali

\begin{abstract}
Microcephaly, is not a disease, is a clinical finding and a simple assessment of decreased intracranial brain volume which is frequently associated with intellectual disability. Abnormal developmental processes which affects in utero neuron development results primary microcephaly at birth. The secondary microcephaly develops after birth and mostly associated with white matter diseases. The underlying etiologies of microcephaly are complex and multifactorial. These include abnormal mitotic spindle structure, centrosomal protein abnormalities, impaired cilia function, damaged DNA repair mechanism and DNA replication. Here we overview the genetic factors of primer congenital and secondary developmental microcephaly.
\end{abstract}

Key Words: Intellectual disabiliy, Microcephaly

\section{GiRiş}

Mikrosefali, tanım olarak oksipito-frontal halkadan ölçülen baş çevresinin yaş ve cinsiyete göre 3 persentil veya -2 standart deviasyon (SD) altında olmasıdır (1). Başın vucudun geri kalanına göre uygunsuz "disproporsiyone" bir șekilde küçük olması bir başka tanımıdır. Şiddetli mikrosefali pek çok kaynakta -3 SD altında mikrosefali olarak tanımlanır (2). Mikrosefali terimi, tek başına bir hastalı̆ı̆ değil bir nörogelişimsel bulguyu ifade eder (2). Mikrosefalinin derecesi çoğunlukla öğrenme güçlüğünün derecesi ile paralellik gösterir, baş çevresinde normal aralıktaki dağlımın, zihinsel kapasite ile ilișkisi zayıf korelasyon gösterirken bu sınırların dışında öğrenme güçlüğü ve zihinsel yetersizlikle ciddi korelasyon gösterdiği saptanmıştır $(2,3)$. Evrimsel süreç boyunca kranyal volüm ve bununla doğrudan ilişkili olarak beyin hacmi giderek artmakla beraber zihinsel kapasitenin artmasında esas önemli olan korteksin genişlemesi ve yeniden

düzenlenmesidir (3). Şiddetli mikrosefali, zihinsel yetersizlik ve santral sinir sistemi gelişimsel anomalileri ile daha çok ilişkili bir durumdur.

Kromozomal hastalıklar, çevresel faktörler ve malformasyon sendromları gibi çok çeşitli etyolojik sebepler nörogelişimsel bir bulgu olarak mikrosefaliye sebep olabilir (Tablo I). Mikrosefalinin bulgularının bir parçası olarak tanımlandığı 450'den fazla malformasyon sendromu vardır. Mikrosefali, tek başına izole bir bulgu olması veya başka malformasyonlar veya dismorfik bulgularla birlikte olma durumuna göre izole-gerçek mikrosefali ve sendromik mikrosefali, ortaya çıkış zamanına ve etyolojisine göre ise primer ve sekonder mikrosefali olarak dasınıflandııılmıştır. Gestasyonun 36. haftasından önce emriyonel-fatal dönemde beyni etkileyen gelişimsel anomaliler ve teratojen etkenler primer-konjenital (doğuştan) mikrosefali oluşumuna sebep olur. Kromozomal hastalıklar, malformasyon sendromları, ailesel mikrosefali, kokain ve alkol gibi kimyasal teratojenler, hipoksi, 
Tablo I: Primer ve sekonder mikrosefali sebepleri.

\begin{tabular}{|c|c|c|}
\hline & Konjenital-primer & Postnatal-sekonder \\
\hline Genetik & $\begin{array}{l}\text { İzole genetik } \\
\text { Otozomal resesif mikrosefali } \\
\text { Otozomal dominant mikrosefali } \\
\text { X'e bağlı mikrosefali } \\
\text { Dengeli komozomal yeniden düzenlenmeler ve ring kromozom } \\
\text { Sendromik } \\
\text { Kromozomal } \\
\text { Trizomi 21,13,18 } \\
\text { Dengesiz yeniden düzenlenmeler } \\
\text { Mikrodelesyon sendromları } \\
\text { 4p delesyonu (Wolf-Hirschhorn sendromu) } \\
5 p \text { delesyonu (cri-du cat sendromu) } \\
7 \text { q11.2 delesyonu (Williams sendromu) } \\
22 \text { 11.2 delesyonu (Di George sendromu) } \\
\text { Tek gen hastalıkları } \\
\text { Kornelia de Lange sendromu } \\
\text { Holoprosensefali } \\
\text { Smith-Lemli-Opitz sendromu } \\
\text { Seckel sendromu }\end{array}$ & $\begin{array}{l}\text { Metabolik hastalık ilişkili } \\
\text { Konjenital glikozilasyon bozuklukları } \\
\text { Mitokondrial hastalıklar } \\
\text { Peroksizomal hastalıklar } \\
\text { Menkes hastalığı } \\
\text { Sendromik } \\
\text { Mikrodelesyon sendromları } \\
\text { Miller-Dieker sendromu } \\
\text { Tek gen hastalıkları } \\
\text { Rett sendromu } \\
\text { Nijmegen breakage sendromu } \\
\text { Ataxia-telenjektazi sendromu } \\
\text { Cockayne sendromu } \\
\text { Aicardi-Goutieres sendromu } \\
\text { XLAG sendromu } \\
\text { Cohen sendromu }\end{array}$ \\
\hline Edinilmiş & $\begin{array}{l}\text { Distrupsiyon hasarı } \\
\text { Monozigotik ikizin intrauterin kaybı } \\
\text { İntrauterin iskemik ve hemorajik inme } \\
\text { Enfeksiyonlar } \\
\text { TORCHES ( Toxoplazma, rubella, sitomegalovirus, } \\
\text { herpes simplex, sifiliz) ve HIV } \\
\text { Teratojenler } \\
\text { Alkol, hidantoin, radyasyon } \\
\text { Maternal fenilketonüri, diyabet } \\
\text { Maternal hipotroidizim } \\
\text { Maternal folat eksikliği } \\
\text { Maternal malnutrisyon } \\
\text { Plasental yetmezlik }\end{array}$ & $\begin{array}{l}\text { Distrupsiyon hasarı } \\
\text { Travmatik beyin hasarı } \\
\text { Hipoksik iskemik ensefalopati } \\
\text { Hemorajik-iskemik inme } \\
\text { Enfeksiyonlar } \\
\quad \text { Menenjit ve ensefalit } \\
\text { Konjenital HIV ensefalopatisi } \\
\text { Toksinler } \\
\quad \text { Kurşun zehirlenmesi } \\
\quad \text { Kronik böbrek yetmezliği } \\
\text { Hipotiroidi } \\
\text { Anemi } \\
\text { Malnutrisyon } \\
\text { Konjenital kalp hastalığı }\end{array}$ \\
\hline
\end{tabular}

intrauterin TORCHES (Toxoplazma, rubella, sitomegalovirus, herpes simplex, sifiliz) ZICA, HIV enfeksiyonları, plasenta ve fetal gelișimi etkileyen maternal hastalıklar, maternal diyabet, maternal fenilketonüri- hiperfenilalaninemi, anemi, hipotiroidi, yüksek ateşli hastalık gibi durumlar nörogenezi etkileyerek beynin normal boyuta ulaşmasına engel olabilir (2). Sekonderedinsel mikrosefalide ise nörogenezis sırasında oluşmuş olan nöron sayısı ve beyin volümü normal olmakla beraber postnatal dönemde dendritik sinaptik ilişkilerin azalmasına sebep olabilen beyaz cevher hastalıkları sözkonusudur. İlerleyici nörometabolik hastalıklara bağlı olarak gelișebilen sekonder mikrosefalide çoğunlukla kranyal manyetik rezonans görüntülemede anormal beyaz cevher bulgusu saptanabilir (2).

\section{Primer Mikrosefali}

Tanım olarak 36. gestasyonel haftadan önce tesbit edilen mikrosefalidir (2). Etyoloji, nörogeneziste, nöron ve diğer beyaz cevher elemanlarının oluşum bozukluğuna bağlıdır.

Nörogenezis basamaklarının sağlıklı tamamlanabilmesi için DNA replikasyonu ve hücre bölünmesinin sorunsuz olması gerekir.
Pirimer mikrosefali oluşumunda temel sebep azalmış hücre bölünme kapasitesi veya artmıș nöroprogenitör hücre ölümüdür. Özellikle mitotik bölünmenin mikrotübül iplikcikleri, sentrozom ve sentriollerin olușumu gibi basamaklarını ilgilendiren mutasyonlar asimetrik hücre bölünmesine ve artmıș apoptoza sebep olup nörogenezisi bozarak primer konjenital mikrosefali oluşumuna sebep olur (4).

Kromozomal bozukluklar, prenatal çevresel ve maternal faktörler (maternal fenilketonüri, diyabet, malnutrisyon, hipotiroidizm, kronik böbrek hastalığı, migren, demir ve folik asit eksikliği, düşük sosyoekonomik düzey), intrauterin enfeksiyonlar, yüksek ateşin eşlik ettiği maternal influenza enfeksiyonları, teratojen ajanlar (kokain, alkol, enfeksiyon, hipoksi, metabolitler), plasental yetmezlik, hipoksi, maternal travma, bazı mitokondrial mutasyonlar ve nadiren de Aicardi-Goutieres sendromunda olduğu gibi erken bașlangıçlı nörodejeneratif süreçler ile serin sentez defekti ve molibden kofaktör eksikliği gibi bazı metabolik hastalıklar primer mikrosefaliye sebep olabilir (2-5). Primer mikrosefali vakalarnın çoğunda baș çevresi -3SD ile -8SD arasında olacak şekilde saptanır. Yirminci gestasyonel 
haftadan önce tesbit edilebilen mikrosefalinin, diğer beyin malformasyonları ile birlikte olma olasilığı daha yüksek ve genellikle prognozu daha kötüdür. Bu gibi vakalarda baş çevresi genellikle belirgin mikrosefalik ( $\leq-8 S D$ ) şeklindedir (5).

Otozomal resesif primer mikrosefali $(\mathrm{MCPH})$, genellikle hafif zihinsel yetersizlik dışında herhangi bir belirgin nörolojik bulgunun olmadığı bir konjenital mikrosefali formudur. Eşlik eden herhangi bir başka malformasyon, anomali, dismorfik bulgu, anormal manyetik rezonans görüntüleme bulgusu veya kromozom bozukluğu yoktur. Boy kısalığı bulunabilir ancak baş çevresi boya göre de mikrosefaliktir. Sıklğı 1/30.000-1/250.000 olarak bildirilmekle beraber akraba evliliğinin sık görüldüğü ülkelerde prevalansı artmıştır. Nörogenezde rol alan, hücre siklusunu düzenleyen, sentrozomal mikrotübül organizasyonu, kromozom kondensasyonu, DNA hasar tamiri, apoptoz kontrolünde görev alan genleri içeren farklı kromozomal lokuslarda 10'dan fazla (MCPH 1-11 genleri), primer otozomal resesif mikrosefali ile ilişkili olduğu tanımlanmıştır (5-7).

Primer mikrosefali, boy kısalığı ile beraber olduğu durumda büyüme geriliğinin orantılı olup olmadığı, baş çevresinin boya göre de mikrosefalik olup olmadığı doğru bir şekilde değerlendirilmelidir. Fankoni ve Bloom sendromu gibi kromozomal instabilite sendromlarında klinik tanı çoğu zaman sitogenetik çalısmalarla doğrulanabilir. Cücelik, ileri derecede intrauterin büyüme geriliği ile beraber mikrosefali olduğunda Seckel sendromu, mikrosefalik osteodisplastik primordial dwarfizm (MOPD) tip I ve tip II gibi tanılar akilda bulundurulmalıdır. Seckel sendromunda mikrosefali ile beraber belirgin gözler ve gaga şeklinde burun tipiktir. Seckel sendromu ve MOPD' de prenatal başlangıçlı şiddetli büyüme geriliği ve șiddetli mikrosefali (-8SD) sözkonusudur. Otozomal resesif kalitlan bu malformasyon sendromlarından Seckel sendromunda, ATR sinyalizasyon yolağı, MOPD I de RNU4ATAC, MOPD II de ise perisentrin gen defekti etyolojiden sorumlu tutulmuştur. Farklı lokuslarda yer alan bu farklı genlerin ortak özelliği hücre bölünmesinde rol almalarıdır (8-10). Seckel sendromundan farklı olarak MOPD de zihinsel yetersizlik daha hafiftir, displastik iskelet değişiklikleri mevcuttur ve büyüme geriliği daha ağırdır (7). MOPD tip I de malformasyonlar daha ağır ve beklenen yaşam süresi kısadır. Ayrıca santral sinir sistemi anomalileri, katarakt, cilt ve diş bulguları da görülebilir $(8,9)$.

Primer mikrosefalinin, dismorfik bulgular ve/veya diğer konjenital anomaliler ile beraber olduğu durumda mutlaka kromozomal hastalıklar araştırımalı, rutin kromozom analizi ile tanı konamazsa moleküler karyotipleme, array bazlı karşılaştırmalı genomik hibridizasyon (array CGH) yapılmalıdır. Çok çeşitli ve farklı sayıda kromozomal bozukluk mikrosefali ile beraber dismorfik bulgular, malformasyonlar ve zihinsel yetersizliğe sebep olabilir. Tüm kromozom hastalıkları ve bazı sık görülen mikrodelesyon sendromları mikrosefali ayırıcı tanısında akılda tutulmalıdır. 1p36 delesyonu, 5p delesyonu (Cri-ducat sendromu) ve $4 p$ delesyonu (Wolf Hirschhorn sendromu), başlıca akla gelmesi gereken durumlardır. Wolf-Hirschhorn sendromunda hipertelorizm ile beraber belirgin burun kökünün oluşturduğu Yunan miğferi şeklinde tariflenen dismorfik bulgu tipik bir tanısal ipucudur $(10,11)$. Mikrosefalinin büyüme geriliği, dismorfolojik bulgular ve/veya konjenital anomaliler ile birlikte olduğu 'Cornelia de Lange sendromu', 'Meier-Gorlin sendromu' gibi diğer bazı mendelyen hastalıklar da tipik dismorfik ve klinik bulguları ile tanınabilir $(12,13)$.

Erken embriyonik dönemde serebral gelişimi bozan faktörler ileri derecede primer mikrosefali (-8 SD) ile beraber erken başlangıçlı dirençli epileptik nöbetlere sebep olabilir. Bu durum genellikle ağır zihinsel yetersizlik, spastisite ve fokal nörolojik bulgular ile birlikte olabilir (2-5).

\section{Sekonder Mikrosefali}

Sekonder mikrosefali, doğumdan sonra gelișen mikrosefali olarak tanımlanır. Altta yatan sebep nörogenezisdeki bozukluk değildir, nöronların veya santral sinir sistemindeki gelişimsel sürecini sekteye uğratan herhangi bir faktör sekonder mikrosefaliye sebep olabilir. Sekonder mikrosefali patogenezinde normal nöronal gelişimin distrupsiyon veya deformasyonu sözkonusudur. Hikaye ve fizik muayene bulguları altta yatan sebebi aydınlatmak için ipucu olabilir. Bozukluğun sabit veya ilerleyici bir bozukluk olup olmadığının tesbiti tanısal açıdan önemlidir.

Eğer statik bir patoloji sözkonusu ve beraberinde dismorfik bulgular ve konjenital anomaliler varsa öncelikle kromozomal bozuklular ve mendelyen tek gen hastalıkları gibi iki ana kategori düşünülmelidir. Mikrosefali sebebi olan kromozomal anomalilerde delesyonlar, duplikasyonlardan daha sıktır, hemen daima beraberinde gelişme geriliği mevcuttur ve sitogenetik anomali ne kadar çok gen içeriyorsa klinik o kadar kötüdür. MillerDiker sendromu 17p13.3 lokusunun delesyonu sonucu oluşur. Daha büyük kromozomal delesyonlar ağır zihinsel yetersizlik, lizensefali, pakigri ve tipik yüz bulgusu ile beraberken; LIS1 genini içeren daha küçük delesyonlar veya LIS1 mutasyonlarında klinik daha hafiftir $(13,14)$. Sekonder mikrosefali ve öğrenme güçlüğü sebebi olabilen bir mendelyen hastalık olarak 'RubinsteinTaybi sendromu'nda, tipik yüz görünümü, el ve ayakta geniş başparmak mevcuttur. Hastaların \% 25'inde 16p13'te lokalize CREPBBP gen bölgesinde delesyon saptanır (15). Tipik yüz bulguları ile tanınabilen bir başka zihinsel yetersizlik sendromu olan 'Pitt-Hopkins sendromu'nda TCF4 fonksiyon kaybı, postnatal mikrosefali, respiratuvar disritmi ve epilepsi bir arada görülür. Sekonder mikrosefali, ilerleyici nörolojik bulgular ile beraber ise nörometabolik hastalıklar ön planda düşünülmelidir ancak bu grup sekonder mikrosefalilerin \% 1'lik bir kısmını oluşturan nadir bir sebebidir (16). GLUT-1 eksikliğinde olduğu gibi metabolik hastalıkların çoğunda doğumda normal olan baş çevresinde gelişimsel regresyon sözkonusudur.

İlerleyici nörolojik bulgularla giden çok sayıda hastalık sekonder mikrosefaliye sebep olur. Rett sendromu, DNA tamir bozuklukları ve Cohen sendromu sekonder mikrosefali sebebi olan mendelyan hastalıklara örnek olarak verilebilir 
(2). Fankoni, Cockayne, Nijmegan breakege gibi DNA tamir defekti sendromlarında mikrosefali, büyüme geriliği ve öğrenme güçlüğü ile beraberdir. Angelman sendromunda mikrosefali şiddetli değildir ancak beraberinde ciddi öğrenme güçlüğü, bozuk ifade dili, nöbet, ataksi, geniş tabanlı yürüyüş bulunur. Tipik yüz bulguları ve gülme atakları tanıda önemlidir (17). PittHopkins sedromunda mikrosefaliyle beraber zihinsel yetersizlik, dirençli epilepsi, kaba yüz ve respiratuar distress görülmesi tipiktir(17).

Mikrosefali bulgusu ile düşünülebilecek diğer bazı tanılardan 'Smith Lemli Opitz sendromunda mikrosefali ile beraber prenatal başlangıçlı büyüme geriliği, yarık damak, gelişme geriliği, konjenital kalp hastalı̆̆ı, genital anomali ve $Y$ şeklinde 2.-3. ayak parmakları arasında sindaktili sık görülür. Smith Lemli Opitz sendromu bir kolesterol sentez defektidir, hipokolesterolemi ile beraber artmış 7-dehidrokolesterol düzeyinin gösterilmesi ve moleküler genetik analiz ile tanı konur(18). Mikrosefali, 'Mowat Wilson Sendromu' tanıı hastaların \% 80'inde görülen bir tanısal bulgudur. Mowat Wilson Sendromu 2q22'de lokalize ZEB2 gen defekti sonucu olușur. Tipik yüz (hipertelorizm, derin yerleșimli gözler, belirgin kolumella) ve öğrenme güçlüğü-büyüme geriliği ile beraber mikrosefali, nöbet, hipospadias, Hirschprung hastalığı, korpus kallozum anomalileri bulunduğunda akla gelmelidir. Yukarı dönük kulak memesi tipik bir tanısal ipucudur (19).

\section{Mikrosefalik hasta öykü ve fizik muayenesinde öncelikle dikkat edilecek ipuçları:}

Aile öyküsünde akrabalık durumu sorgulanmalı ve üç nesil aile ağacı çizilmelidir. Prenatal enfeksiyon, ilaç, radyasyon ve alkol maruziyeti, mikrosefalinin tesbit edildiği gebelik haftası sorgulanmalıdır. Doğum kilosu, gelişim basamakları ve nöbet hikayesi ayırıcı tanıda bize yol gösterebilir.

Baş çevresi ve diğer büyüme parametrelerinin birlikte değerlendirilmesi, mikrosefalinin derecesinin saptanması, ebeveynlerin baş çevresi ölçümü, dismorfik bulguların değerlendirilmesi, diğer konjenital malformasyonlar ve detaylı nörolojik muayene bizi olası bir spesifik tanıya götürebilir. Yaş ve cinsiyete göre mikrosefalinin derecesi standart deviasyon cinsinden derecelendirilebilir (2).

Çevresel faktörler, enfeksiyonlar, travma, prenatal ve posnatal teratojenler mikrosefali etyolojisinde mutlaka sorgulanması gereken durumlardir.

\section{Mikrosefalik hastada tanısal tetkikler:}

1. Kranyal görüntüleme, her hastada zorunlu değildir, pek çok pediatrik hastada sedasyon veya genel anestezi gerektirir. Fakat primer mikrosefali BÇ $\leq-6 S D$, ağır zihinsel yetersizlik erken başlangıçlı epilepsi, spastisite gibi motor bulgular veya otozomal dominant holoprosensefali gibi aile hikayesi varlığında kranyal görüntüleme yaparak serebral formasyon hakkında bilgi sahibi olmak tanısal açıdan gereklidir. Mikrosefalik hastaların \% 61'inde anormal nörogörüntüleme bulgusu vardır, bu oran şiddetli mkrosefalide \% 75-80 olarak saptanmıştır (14). Kranyal manyetik rezonans görüntüleme yapısal beyin malformasyonların ve migrasyon anomalilerini tesbit etmemizi sağlar.

2. Biyokimyasal ve serolojik testler, düșündüğümüz hedef bir tanı varsa doğrulamak veya dıșlamak için gerekli olabilir. Göz muayenesi, TORCH serolojisi, sifiliz ve parvovirus enfeksiyonları için serolojik tarama, maternal kandan fenilalanin analizi, kan aminoasitleri ve idrarda organik asit analizi, hasta hipotonikse uzun zincirli yağ asitleri analizi, beraberinde sindaktili ve yarı damak varsa Smith-Lemni Opitz sendromu düșünüldüğünde azalmış kolesterol seviyesi ile beraber artmış 7-dehidrokollesterol düzeyi tesbiti olası bir metabolik hastalığa tanı koymamızı sağlayabilir.

3. Oftalmolojik ve odiyolojik testler, mikrosefalik hastalarda \% 6,4 oranında oftalmik patoloji ve \% 23 oranında işitme kaybı saptanmışıı (15).

4. Hedefe yönelik tanısal testler, hastalığa özgün genetik testler klinik bulguları değerlendirierek, şüphelendiğimiz özgün bir tanı varsa hedefe yönelik olarak yapıldığında etyolojiyi aydınlatmada yüksek başarilı testlerdir.

5. Gen panelleri, öncelikle primer otozomal resesif mikrosefali düşünüyorsak MCPH gen lokuslarını analiz edebilmek için DNA analizi, mikrosefali ile ilișkilendirilmiș gen lokuslarını topluca dizilemeye imkan verecek gen panelleri ile tetkik tanısal açıdan faydalı olabilir.

6. Mikroarray testi, Öncelikle sayısal veya yapısal kromozomal hastalıklarını dışlamak için yüksek çözünürlükte bir kromozom analizi, $1 p, 4 p, 5 p$ ve $8 p$ kromozomal lokuslarının sık görülen delesyonları için subtelomerik FISH analizi, diğer mikrodelesyon/ duplikasyon sendromlarını dışlamak için ise array CGH analizi yapılmalıdır. Array $\mathrm{CGH}$ analizi, kromozom analizine göre daha yüksek rezolüsyonda olup daha kapsamlı anomali tarama testine olanak verir. Mikrosefali, zihinsel yetersizlik, boy kısalı̆ı, dismorfik bulgular ve diğer konjenital anomalilerle beraberse mikroarray testi yapmak gereklidir.

\section{Genetik Danıșma}

Prenatal ultrasonografi ile primer mikrosefalnin fark edilmesi 3236. haftaları bulabilir. Sadece şiddetli primer mikrosefali olguları 20. haftadan önce tanı alır.

Mikrosefaliye sebep olabilecek çevresel faktörler ve diğer sendromlar dikkatli bir değerlendirme ile dışlanmış ve kranyal görüntülemede yapısal malformasyon saptanmamışsa primer otozomal resesif mikrosefali tanısı muhtemeldir ve ailelere \% 25 tekrar riski anlatılabilir. Eğer hastaya başka özel bir tanı konulmuşsa konuya-tanıya özgün genetik danışma verilmelidir.

\section{SONUÇ}

1. Mikrosefali bir hastalık değildir, azalmış beyin hacmine işaret eden önemli bir klinik bulgudur. 
2. Intrauterin nöron üretiminin azalmasına sebep olan bozuk nörogelişimsel süreç 'primer mikrosefaliye' sebep olur.

3. 'Sekonder mikrosefali' doğumdan sonra dendritik veya beyaz cevher hastalıkları sonucu gelişir.

4. Mikrosefali, pek çok farklı sebep sonucu oluşabilen heterojen bir durumdur. Ayrıntılı öykü, fizik muayene ve kapsamlı genomik testlerle, mikrosefali ile ilişkili genetik faktörlerin belirlenmesi mümkündür.

\section{KAYNAKLAR}

1. Opitz JM, Holt MC. Microcephaly: general considerations and aids to nosology. J Cranio fac Genet Dev Biol 1990; 10: 175-204.

2. Woods CG, Parker A. Investigating microcephaly. Arch Dis Child 2013; 98: 707-713.

3. Gilbert SL, Dobyns WB, Lahn BT. Genetic links between brain development and brain evolution. Nat Rev Genet 2005; 6: 58190.

4. Alcantara D, O’Driscoll M. Congenital microcephaly. Am J Med Genet C Semin Med Genet 2014; 166C: 124-39.

5. Elçioğlu, H. Nursel; Salim, Mahmoud. Mikrosefali. Turkiye Klinikleri Journal of Pediatrical Sciences, 2013; 9: 39-46.

6. Abdel-Hamid MS, Ismail MF, Darwish HA, Effat LK, Zaki MS, AbdelSalam GM. Molecular and phenotypic spectrum of ASPM-related primary microcephaly: Identification of eight novel mutations. Am J Med Genet Part A 2016; 170: 2133-40.

7. Thornton GK, Woods CG. Primary microcephaly: do all roads lead to Rome? Trends Genet 2009; 25: 501-10.

8. He H, Liyanarachchi S, Akagi K,Nagy R, Li J, Dietrich RC, et al. Mutations in U4atac snRNA, a component of the minor spliceosome, in the developmental disorder MOPD I. Science 2011; 332: 238-40.

9. Rauch $A$. The shortest of the short: pericentrin mutations and beyond. Best Pract Res Clin Endocrinol Metab 2011; 25: 125-30.
10. Willems M, Geneviève D, Borck G,Baumann C, Baujat G, Bieth $E$, et al. Molecular analysis of pericentrin gene (PCNT) in a series of $24 \mathrm{Seckel} / \mathrm{microcephalic} \mathrm{osteodysplastic} \mathrm{primordial} \mathrm{dwarfism}$ type II (MOPD II) families. J Med Genet 2010; 47:797-802.

11. Ütine GE, Şimşek-Kiper PÖ, Boduroğlu K. Mikrodelesyon sendromları. Çocuk Sağlığı ve Hastalıkları Dergisi 2012; 55: 4251.

12. Schrier SA, Sherer I, Deardorff MA,Clark D, Audette L, Gillis L,et al. Causes of death and autopsy findings in a large study cohort of individuals with Cornelia de Lange syndrome and review of the literature. Am J Med Genet A 2011;155: 3007-24.

13. de Munnik SA, Bicknell LS, Aftimos S,Al-Aama JY, van Bever Y, Bober MB, et al. Meier-Gorlin syndrome genotype-phenotype studies: 35 individuals with pre-replication complex gene mutations and 10 without molecular diagnosis. Eur J Hum Genet 2012; 20: 598-606.

14. Kato M, Dobyns WB. Lissencephaly and the molecular basis of neuronal migration. Hum Mol Genet 2003;12: 89-96.

15. Hennekam RC. Rubinstein-Taybi syndrome. Eur J Hum Genet 2006;14:981-5.

16. Ashwal S, Michelson D, Plawner L, Dobyns WB; Quality Standards Subcommittee of the American Academy of Neurology and the Practice Committee of the Child Neurology Society. Practice parameter: Evaluation of the child with microcephaly (an evidencebased review): report of the Quality Standards Subcommittee of the American Academy of Neurology and the Practice Committee of the Child Neurology Society. Neurology 2009; 73: 887-97.

17. Seltzer LE, Paciorkowski AR. Genetic disorders associated with postnatal microcephaly. Am J Med Genet C Semin Med Genet 2014;166C:140-55.

18. Nowaczyk MJ, Irons MB. Smith-Lemli-Opitz syndrome: phenotype, natural history, and epidemiology. Am J Med Genet C Semin Med Genet 2012;160C:250-62.

19. Garavelli L, Mainardi PC. Mowat-Wilson syndrome. Orphanet J Rare Dis 2007; 24; 2:42. 